\title{
African Naturalists, Collectors and Taxidermists
}

A close reading of Barber's and her contemporaries' sources shows that European travellers and settler naturalists were not diverging from African experts and their knowledge. Drawing on what Bruno Latour calls 'cycles of accumulation', ${ }^{1}$ historian Nancy Jacobs has claimed that the more ornithologists knew, the less dependent they were on what she calls 'African vernacular birders'. ${ }^{2}$ It is true that Barber and her contemporaries did not speak of Africans' knowledge and rarely used vernacular species names as they were in the midst of a process of formulating their own terms of this new information and appropriating it to so-called Western science. The more published sources they had access to on how Africans used medicinal and nutritional plants, the more they could build on the results of earlier settler-African knowledge exchange. Primary and secondary accounts of African knowledge now went hand in hand. African expertise translated by settlers or people in Europe was circulated in the same way as directly acquired information. Some European experts in the second half of the nineteenth century might have credited African experts less often or less favourably than their predecessors, but their ties were as strong as ever.

This chapter focuses on collectors, informants and taxidermists. ${ }^{3}$ These categories were often overlapping, but it is useful to consider them one by one. Given that there are far fewer sources on African taxidermists, the last subsection will inevitably be shorter. The description of the collectors in the next section could have benefited from a closer examination of the

T. Hammel, Shaping Natural History and Settler Society, Cambridge Imperial and Post-Colonial Studies Series, https://doi.org/10.1007/978-3-030-22639-8_3 
European naturalists. Yet, I deliberately chose not to devote too much space to them and rather focus on the African collectors.

\section{Collectors As Companions}

African collectors feature in European travellers' accounts throughout the nineteenth century, as the following three examples show: Stoffel Speelman, a Khoekhoe collector, collaborated closely with the English naturalist William John Burchell (1781-1863), who travelled widely in Southern Africa between 1810 and 1815 . He was one of various 'Hottentots' - up to ten at a time-who worked with Burchell. None of his African collaborators stayed with him throughout his journey. ${ }^{4}$ African collectors often paid great attention to detail and knew far more of the habits of wild animals than newcomers did, which is why they were much better at finding and killing animals than Burchell and other European travellers. They deduced information from various surroundings and situations, and their knowledge 'proved of the utmost importance' for Burchell's endeavour. ${ }^{5}$ In 1811, Burchell employed Speelman, who had just arrived in Cape Town two months after being discharged from the Cape regiment and was employed 'as herdsman' when he caught Burchell's attention. At the time, Burchell had already found three Khoekhoen collaborators 'one to drive the waggon, another to lead the team, and the third to take charge of the loose oxen'. 6 Speelman agreed to accompany Burchell if his wife could join him. Burchell negotiated with Speelman's employer, who let him go.

Speelman was about forty years old, tall, thin, upright, active and intelligent. 'His eyebrows were stronger than usual in this nation [more European-like]; his cheek-bones protuberant; cheeks hollow; nose flattened and wide, with large distorted nostrils $[\ldots]$, the chin narrow, $[\ldots]$; and the beard very scanty, excepting on the upper lip.' He was 'an excellent marksman', 'a great traveller, and had visited most parts of the colony'. He had long wished to go to Klaarwater and was motivated to join the travel party by the prospect of seeing the country beyond the Gariep (Orange River) again. ${ }^{7}$

His wife Hannah was about thirty years old and unusually big for a Khoekhoe woman. She had small hands and feet, a long jutting chin and short black woolly hair under a kerchief around her head, wearing a 'coarse linen dress made in the Dutch fashion, and shoes of raw hide covered her feet'. Burchell did not want her to accompany them. Realising that Speelman would not join without her, he agreed to her joining on the 
condition that he could engage her for cooking and washing. These two occupations, seen as women's tasks by Europeans, did not appeal to Hannah from the beginning and later did not satisfy her at all. ${ }^{8}$ Having a woman cook on an expedition was also rather unusual. At the district secretary's, Burchell and Speelman made a contract, with copies for all three of them, that registered Speelman's wage, his duties and his freedom to leave after the period of employment.'

Whatever struck Speelman as 'curious', he would collect and show his companions. ${ }^{10} \mathrm{He}$ was a creative individualist with a strong sense of fashion that was much admired by his wife Hannah. The military full-dress cocked hat given to him by his comrades in Cape Town he did not find fashionable. He loosened the brim to give it a wider and more impressive appearance and sometimes let it down completely like a parasol. He combined this hat with a short blue jacket, sheepskin breeches, naked legs, his gun on his shoulder and powder horn by his side. ${ }^{11}$ Even though it was hot, he wore his 'watch-coat' when he went to his new domicile at Klaarwater to appear more important, since few could afford such a dress there. ${ }^{12}$ Burchell described him as 'the dandy of their party', as he 'dressed in his own fashion'. ${ }^{13}$ On the one hand, the description of clothing shows how Speelman used it as a sign of status. On the other, it is a colonial trope ridiculing how a Khoekhoe nearly, but not quite, pulled off white conventions. He combined European clothes of various kinds-the hat with a blue cloth jacket, new leather trousers, blue knee-long cotton stockings, a pair of leather gaiters, a new pair of leather shoes (Fig. 3.1).

Speelman's expertise in dressing, and the status he displayed, was matched by his initiative, creativity and knowhow in food and animal collecting. Once he and one of his colleagues came across twenty-six ostrich eggs which they wanted to carry to the camp. To Burchell's astonishment, they knotted bags that enabled them to do so. ${ }^{14}$ Initially employed as a 'herdsman', Speelman showed his interest and talent as a 'huntsman', and the more Burchell realised his 'cordial interest in the business of the journey', the more he granted him freedom to collect specimens. ${ }^{15} \mathrm{He}$ was provided with a gun and was allowed to shoot every variety of bird that he came across, which he had to let others carry to the camp or bring back himself. He could collect what he was interested in, when and where he wanted without supervision. He could choose to sleep elsewhere and happily did, taking his 'budget', which meant his ration of food, and a bundle of sheep skins to lie on slung at his back; his gun over his shoulder, 'a kéeri (a short knob-stick)' in his 
Fig. 3.1 Portrait of the Khoekhoe collector Stoffel Speelman. Burchell, Travels in the Interior of Southern Africa, Vol. 1, Fig. 2, facing page 167

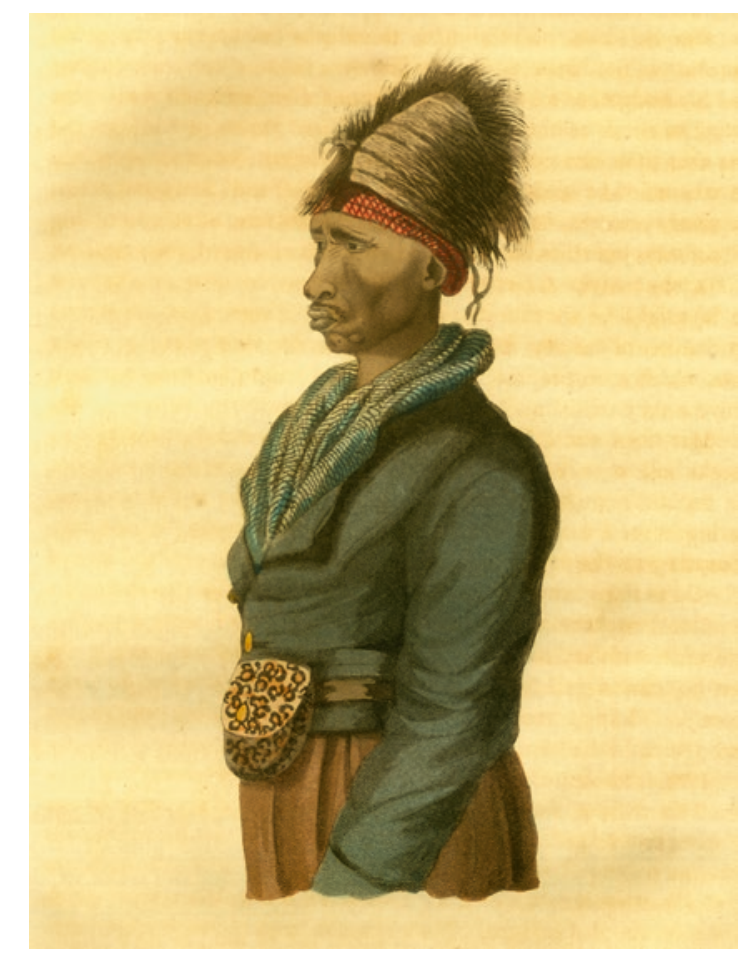

hand; and a short clumsy wooden pipe smoking in his mouth, which to Burchell indicated his pleasure and contentment. ${ }^{16}$ Speelman found many birds that Burchell had not seen before. ${ }^{17}$ When he came across and killed a springbok, zebra, kudu, rhinoceros or hippopotamus for dried meat, he hired locals, sometimes San, to help with carrying. ${ }^{18}$ He also ground corn and played the violin. ${ }^{19}$ On several occasions when Burchell had difficulty finding more African co-workers, Speelman helped recruiting them. ${ }^{20}$ Speelman knew a lot of birds by their colonial names and found very rare ones that they only encountered once during their travels. ${ }^{21}$ Speelman collected more birds than any other of his African colleagues. Burchell openly admitted this fact and that Speelman's knowledge far exceeded his own, which is why he ranked himself below his associate. ${ }^{22}$ At the same time, Burchell noticed that his African co-operator did not treat his wife Hannah very well, keeping her share of tobacco and brandy for himself, which made her even more frustrated with her work. However, 
Burchell did not reprimand Speelman. The male bond was stronger, and Speelman would always bring interesting birds or insect specimens that Burchell valued so much, everything else became secondary. ${ }^{23}$

Speelman spent much time hunting, checking when danger or uncertainty was near and educating his companions. ${ }^{24}$ He told Burchell that the secret in hunting rhinoceros, for instance, was that they could smell humans from a great distance, which is why you always had to approach them from leeward, against the wind. Doing so you had to be silent, as they also heard incredibly well and on hearing the smallest noise would flee very fast. If disturbed, they often furiously followed their hunters, which was dangerous; yet their sight was weak, so you could make them run after you, run away and then have time to load your gun and shoot. ${ }^{25}$ When Speelman was on special expeditions or missions, he often took Khoekhoe comrades with him whom Burchell put under his command. ${ }^{26}$ Speelman greatly enjoyed hunting, was the foremost in hunting parties and the most successful. Yet when circumstances required it, he served in a variety of other ways too, as he was found to be very intelligent and adaptable. His companions also regarded him as the grand almanac-maker. He had a good memory of past occurrences that he could relate in great accuracy; if he was in doubt, he would pull out his almanac, which he had always in some part of his dress. ${ }^{27}$ In short, Speelman did whatever Burchell did and was more successful, which made him his best partner and most dangerous competitor. This becomes more and more apparent in the second half of the second volume of Burchell's Travels in the Interior of Southern Africa. Indeed, when reading Burchell's account, one often has the impression that Speelman was more in command of the expedition than Burchell was. Yet, Burchell made clear that Speelman always required 'the superintendence and guidance of a master'. He also complained that Speelman thought he had privileges, as he was 'an old servant' and felt more attached to Burchell than others, which also led to tensions and conflicts within the travel party. ${ }^{28}$

Of similar importance was Ia to the Swedish collector and ornithologist Johan August Wahlberg's (1810-1856) endeavour while travelling through Southern Africa from the late 1830s to the mid-1850s. Wahlberg left a brief travel account, written in key words, that was edited in 1994 and provides insights into the importance of African collectors to his work. Unfortunately, Wahlberg neither recorded Ia's age, origin nor full name. Wahlberg claims to have been able to communicate in isiZulu and other African languages, yet the names he provides of the African experts he 
collaborates with sound bizarre and out of keeping with any African naming practise. ${ }^{29}$ At times eleven to fourteen African 'companions', as he called them, worked with him. If they had achieved something extraordinary, or even if it was just that they had started their work with him, their names were recorded in his chronicle-like account. Wahlberg's 'companions' seem to have constantly changed, which might explain why he never mentioned when somebody left his group. ${ }^{30}$ Wahlberg constructed himself as superior and more liberal than Dutch and British settlers by criticising them for how they treated the 'indigenous inhabitants'. He defended 'a run-a-way servant', criticised when a Khoekhoe was beaten to death and reported that three Xhosa were shot and the killer got no punishment. ${ }^{31}$ Like Burchell, Wahlberg also established a hierarchy among his cooperators. Those who had proved reliable got the more demanding tasks that required accuracy and trustworthiness. Most of them began as carriers, wagon drivers or translators but could rise to the position of a collector and guide or 'ghillie Kaffer' (hunt master). ${ }^{32}$ Ia had become Wahlberg's personal assistant. When Wahlberg lost parts of his belongings, Ia looked for them. When Wahlberg wanted to catch birds, Ia helped him arrange stones to do so. Ia shot and collected specimens for Wahlberg's collection as well as for food. He also followed the honey guide to provide Wahlberg and his team with honey. ${ }^{33}$ Ia was trusted and given more responsibility than others, and Wahlberg worked closest with him. When they slaughtered animals, Ia did not have to carry the animals alone. Wahlberg helped him, which indicates that Ia was his partner, and he aimed at equal division of labour. ${ }^{34}$ There were also 'Tjobala' with whom Wahlberg looked for elephants, 'Kåtjåiå, Kaljan, Teillsa and Tångo' who were 'hired for a month in exchange for iron for hoes, for combarger', ten men employed for blankets and small trifles, 'Swart Boj herdboy', a 'younger Kaffer' carrying stuff around and in dangerous situations such as when wading through a river full of crocodiles, a 'Kaffer with his assegai ready poised' had to walk in front of him. ${ }^{35}$

Similarly, Gert, a 'Koranna' from the neighbourhood of Klipdrift, started off as an interpreter for the Czech explorer Emil Holub, ${ }^{36}$ by merit was increasingly relied on as an informant and collector, and became Holub's closest African associate. When Holub looked for special insects in a wood, Gert accompanied him and found goat chafers and two kinds of bark beetles (Bostrichidae). They observed the environment and upon finding many gnu skulls they guessed together that, in the past, these animals had frequented the area and then retreated into the interior; this 
indicates that Gert was not only good at collecting but also theorised about what he observed. ${ }^{37}$

Gert was paid 'at the rate of $8 \mathrm{~s}$. 6d. a week' by Holub in the 1870s, where previous explorers had just given their team blankets and goods in exchange for labour. According to the South African archivist and genealogist George McCall Theal (1837-1919), a slave earned 'between 1s 8d and $2 s^{\prime}$ of which it is unclear how much they could keep. ${ }^{38}$ That slaves earned a salary was a very unusual, period and place-specific practice called 'renting out'. ${ }^{39}$ Unskilled coloured workers in Cape Town earned 12.19 grams of silver a day between 1851 and 1875 and 10.70 between 1876 and $1900 . .^{40}$ In a week, this would make around 70 grams of silver, which would have equalled 12.5 shillings. ${ }^{41}$ Gert also received board and lodging. Presumably, the salary in rural areas was lower, which indicates that the pay was acceptable but not the prime motivation for doing the job. Like Speelman, he seemingly enjoyed the scientific research and travelling. Holub, for instance, relates that Gert told him about the yellow crowned $m \hat{a}$-hems, the 'crowned or royal crane (Balearia regtdorum)', that they encountered and that, according to Gert, everybody knew in Africa. Farmers in the Transvaal and the Free State are said to have kept them as pets, which indicates that he had learned much on previous journeys. ${ }^{42}$

Gert, 'a Koranna half-breed' ${ }^{43}$ is the punctum of the image which Nancy Jacobs uses in her introduction to Birders of Africa: History of a Network (2016) to emphasise and illustrate the essential interactions of ornithologists and vernacular birders in Africa. ${ }^{44} \mathrm{He}$ is in command of the situation, explaining to three European travellers that the bird he is showing to them is a grey crowned crane (Balearica regulorum) that the Europeans see for the first time. Holub, the man with the gun, ${ }^{45}$ is ready to shoot it. Gert explains that the $m \hat{a}$-hem has hair on its head not feathers, and was kept as a pet by Afrikaners. ${ }^{46}$ His body language suggests he was ready to defend the bird against Holub or that he tried to persuade him not to shoot.

In other instances, Holub was impressed by the various ethnic groups' hunting techniques in South Africa. He described how the 'Batlapins' used a kiri, a popular tool among the amaZulu and Tswana that was used to kill birds and was much better than the European weapons which destroyed their skins. ${ }^{47}$ The kiri was generally made of wood. ${ }^{48}$

Men and women scientists at the frontier differed in how they related to their co-operators. The three cases above indicate that men narrowed their dependence on African skill by hiding their wider dependence on 
many and emphasising a reliance on one exceptional individual instead. African expertise was thus paradoxically acknowledged, but confined to one exceptional man, the 'friend', while African ability at large was denigrated, ignored or silenced. This was achieved by describing men's bonding across cultures that occurred as a colonial trope; by highlighting one man as their friend, Burchell, Wahlberg and Holub each glorified themselves as exceptional European explorers with whom those remarkable Africans chose to spend periods of time with. They thereby stressed that Speelman, Ia and Gert and themselves were two of a kind and both extraordinary. ${ }^{49}$ Dependency at the frontier was turned into a story of companionship and friendship. Sometimes, there are homoerotic undertones. Jacobs has, for instance, investigated the American naturalist George Latimer Bates's 'same-sex longings' and his ideal of a 'homosocial community' with 'bulu boys' while 'birding' in Cameroon. ${ }^{50}$

While men can in all innocence be companions and friends, ${ }^{51}$ women could not enter into such a construction without appearing sexualised and inappropriately close to an African man. Barber therefore remains vague on who collected for her, and did not build her associates into the tale of the exceptional 'man-servant' at her side. In 1833, her father had tried to sell ornithological specimens in England via her mother's brother-in-law James Renshaw, of Westbourne Lodge, Middlesex, but soon abandoned it, as it was no financial success. ${ }^{52}$ Her brother Bertram Egerton sold stuffed birds to a Prussian apothecary in his youth. ${ }^{53}$ It remains unknown who collected and stuffed these birds, but quite possibly, they came from her and her unrecorded helpers. In one of Barber's nature tales aimed at publication, ${ }^{54}$ she describes how in the spring of 1854 , 'Gavani a tall strapping Kafir' on Highlands helped 'the boys' remove sparrow eggs and feathers from the swallows' nests shortly before the swallows returned. ${ }^{55}$ Given that Barber meticulously recorded the names of her relatives and the details of how they collected specimens for her, it is highly unlikely that 'the boys' refers to her sons or nephews. 'The boys' did so because both the amaXhosa and the settlers believed that the swallow (inkonjane inethamsanqa $)^{56}$ brought good luck when it built its nest on or near a house. ${ }^{57}$ Burchell had already written that in most countries there are some few birds to which man has allowed the privilege of approaching him without molestation', and at the Cape, this was the swallow and the Cape wagtail. ${ }^{58}$ Gavani may well have collected birds for Barber.

Barber had problems 'killing moths and grasshoppers' and often waved them away 'because it was such a struggle to kill them, they cling to their 
little lives so ardently that one wonders whether one really has the right of putting an end to it'. She either heroised herself or hinted at having relied on African collectors for this unpleasant task. She was of the opinion that 'butterflies [were] the only creatures that die respectably, a loving squeeze across the thorax and there you have them!', which explains her focus on Lepidoptera. ${ }^{59}$ 'A Kafir wagon driver', who remains anonymous, was interested in entomology and collected butterflies for Barber. It is not recorded how long they collaborated and which specimens he caught. Presumably he was the one who netted much of what she collected during her journey in 1879. One day he brought her 'a fine Papilio' that she found 'a little spoiled'. She therefore decided to write 'a few simple rules to aid my friends in making up a good collection' ${ }^{60}$ Whether she wrote this manual for African collectors, to whom she referred to as her 'friends', or for Western collectors in a radical switch of operation remains ambiguous. Immediately after this passage, Barber wrote about the mantis habitually damaging butterflies. ${ }^{61}$ Yet, she did not believe that this insect had damaged the above-mentioned butterfly collected for her. Neither did the thought occur to her that the providing of a damaged butterfly could be interpreted as an act of resistance. The entomological collector could also not have felt appreciated for his work and aimed at irritating her by providing her with a damaged specimen.

In matters of racial mix, particularly, the narrative device of 'the exceptional male servant' for a European explorer, a story of reflected glory, was not available with the same ease for a woman naturalist scientist. It is therefore understandable that Barber did not go into detail and remained vague on who her co-workers were and whether they were men or women. The 'Black Peril' discourse in many colonies, and particularly in South Africa and Southern Rhodesia in the nineteenth and twentieth centuries, prevented white women from openly entering such relationships or leaving testimonies of them. ${ }^{62}$ None of the women botanists or botanical artists at the Cape-such as Tongaat-based orchid specialist Katharine Saunders (1824-1901), the British botanical oil painter Marianne North (1830-1890) who visited the Cape in 1883, and one of the first woman members of the Linnean Society Alice Pegler (1861-1929)—referred to close men African associates in detail; instead, they mentioned groups of people or the young women who supported them. ${ }^{63}$ Literary works also remarkably often circumnavigated close ties between white women and indigenous men. In Uncle Tom's Cabin; or, Life Among the Lowly (1852) by the American author Harriet Beecher Stowe, the white woman is a child; in the Australian Jeannie Gunn's (pen name: Mrs. Aeneas Gunn) 
novels based on her time in the outback such as The Little Black Princess: A True Tale of Life in the Never-Never Land (1905) and We of the Never Never (1908), the bonding is between an Australio-European woman and a young Aboriginal girl.

\section{Informants As Providers of 'Soft Facts'}

Coming from communities who had been in place for generations, African informants with their vast experience of local flora and fauna were crucial for every outsider trying to make sense of the environment. In archaeology, African informants, collectors and excavators were of the utmost importance from the start. The German explorer and geographer Karl Gottlieb Mauch (1837-1875), for instance, relied on African experts on his mission to find the lost biblical city of Ophir in 1871-1872. Ophir had been described as the source of the gold given to King Solomon by the Queen of Sheba. Mauch encountered the archaeological ruins of Great Zimbabwe. Mauch often only mentioned them when criticising them: 'No sleep at night, at day plagued by black, two-legged rabble which feels superior in their foolish pride than the white man; they beg for whatever their eyes see and when not benevolently provided what they wish for, they readily take hold of it. ${ }^{64} \mathrm{He}$ had travelled with a group of about forty African co-operators who had contributed hugely to the significance of the find, as had the Shona people they encountered on the way. ${ }^{65}$ Barber and her brothers all acquired their collections in collaboration with Africans, as examples show where Barber and James Henry Bowker closely collaborated with Xhosa and Zulu experts in ornithology and zoology. Barber and the Bowkers must have acted similarly to the anthropologist Monica Wilson (1908-1982), who in the Pondo community in Ntibane kept a bag of tobacco 'which helped the conversation along'. This was seen as sufficient compensation for valuable information and made acknowledgement by name superfluous. ${ }^{66}$ Given that Barber, on her way to establish her reputation as a naturalist, first presented herself as a reputable collector and illustrator, it is highly likely that she consciously silenced her collaboration with African collectors in order to appear independent.

The illustrations in Holub's travel account provide insight into crosscultural co-production of knowledge, as noted above. In an illustration entitled 'A Barolong Story-teller', we see Holub and his European colleague in sceptical postures. The associate on the left (possibly Gert) is 
evidently mediating between Africans and Europeans: his stance indicates that he is in-between the two cultures that meet in this third space. This scene shows a men's network of exchange. The agency lies with the storyteller, the proud man behind him and their companion, who are free to share whatever knowledge they see fit possibly enjoying the strangers' dependence on them. They are on eye-level with Holub's colleagues who nevertheless do not seek eye contact with them.

The Tswana gave Holub and his travel group advice on how to travel in their area, warned them that there were daring lions who killed domestic animals and people. Holub described that he wanted fresh bullocks as one of them had died, and therefore displayed goods that he had brought to trade for scientific specimens. Even though the chief personally came to talk to Holub, Holub lamented that he could not negotiate with anyone for what he had hoped for. ${ }^{67}$ Yet, he was grateful that some of the 1000 villagers entered into conversation and shared some insights with the party.

Barber learned about birds from her Xhosa informants. There are no contemporary sources in isiXhosa or by Europeans on what the amaXhosa knew about birds. The oldest written source is the Scottish missionary Reverend Robert Godfrey's collection published in 1941. His study contains isiXhosa and isiZulu bird names, idioms, stories, bird song interpretations and comments on natural history, mostly from pupils' essays. ${ }^{68}$ The information had derived from the time when Godfrey had joined the United Free Church of Scotland mission at Pirie in 1907 and collected bird specimens in that area. Yet, Barber's sources allow us a glimpse into her and the consulted African experts' co-production of data on birds. This was common practice at the time, as Edgar Leopold Layard's Birds of South Africa (1867) indicates, to which Barber had contributed. Layard, the curator of the South African Museum, hesitated to travel; instead, he observed and collected birds close to home. ${ }^{69} \mathrm{He}$ relied on literature and his wide correspondence network; no wonder, then, that there are few African vernacular names in his publications. Thirteen of the 702 listed species' names probably originated in Africa among speakers of West African, Malagasy, Khoesan, Germanic and Bantu languages. He and his informants did not acquire them through conversing with Africans, but took them from earlier ornithological studies. ${ }^{70}$

Barber accumulated information on birds partly in that way, as this example shows: a bird that has attracted considerable attention and that deeply fascinated Barber is the honey guide. She was convinced that the bird led to honeycombs but not to snakes or leopards as David Livingstone 
and other Europeans had discussed at length. ${ }^{71}$ That indigenous animals and people were treacherous and led Europeans into danger was a widespread colonial fantasy. Barber argued that many experienced beehunters - among the amaXhosa, amaMfengu and Khoesan as well as settlers-had never been led to a noxious animal on purpose and that the honey guide would not waste its time leading to animals such as leopards, jackals and wolves, which were not its natural enemies and would therefore in no way benefit the honey guide. Furthermore, she observed that the honey guide did not alter its voice when encountering animals on the way to honey, which she saw as an additional reason against the popular belief. ${ }^{72}$ In her 'Plea for Insectivorous Birds' (1886), a paper read to the local Natural History Society and published in the Graham's Town Journal as one of her attempts at protecting species, Barber also mentioned that the honey guide was not included 'in the doomed list of "Kill! Kill! Kill!!!" due to its pointing to honey stores and being 'a small brown bird of no beauty', unlike other cuckoos. ${ }^{73}$ In a poem entitled 'To my Brother', for James Henry Bowker, she wondered:

\author{
'wise little bird whence came thy skill \\ To know and comprehend man's will? \\ Who taught thee' mid the deep wood's shade \\ To call his service to thine aid \\ to tempt him on from tree to tree \\ To serve thy purpose cunningly'? ${ }^{74}$
}

Barber consistently referred to the bird as 'she' and stressed the bird's superiority in understanding humans better than they did the bird. Yet, Barber does not say where she had heard about the honey guide. She might either have learned from the amaXhosa, who described it as intakobusi ('the bird of the honey') or intake yeenyosi ('the bird of the bees'), a term that the colonists used as the basis for naming it the honig-wyzer and honey-guide. In isiXhosa, intakobusi was-in the mid-twentieth-centuryapplied figuratively to a human who shared its 'pertinacity' in two different senses: 'it may be used of one who, by reason of his position or his clan, is able to plead sweetly and persuasively for others with a chief or headman; or it may be applied to a garrulous wheedling person. ${ }^{375}$ These proverbs may already have been in use in the nineteenth century, as many European idioms were. Barber might also have learned about the honey guide from previous European expedition journals, such as the one published by Andres Sparrman. ${ }^{76}$ All in all, Barber's encounters with the 
honey guide and knowledge of its behaviour reveal how she observed birds and discussed observations with others.

Barber did not mention divergence of amaXhosa and settlers' encounters with birds. On the contrary, she stressed their co-operation and shared views on birds. She had no interest in supplying information such as George McCall Theal's in 'The Story of the Bird that Made Milk' in Kaffir Folk-Lore or, A Selection from the Traditional Tales Current Among the People Living on the Eastern Border of the Cape Colony (1882), in which he stereotyped the amaXhosa as naïve, greedy, egoistic, patriarchal and violent. ${ }^{77}$ The amaXhosa saw starlings such as the red-winged isomi as mediators between humans and ancestors, and birds of good fortune. ${ }^{78}$ Barber learned from the amaXhosa-probably on her relatives' farms-which birds they regarded as 'birds of the house' with a good omen and which birds mediated between the living and the ancestors. Her family equally valued the birds that the amaXhosa treasured, and they never shot any of the birds that took 'their abode with' them. This allowed Barber to observe these birds and 'all their odd ways'. ${ }^{79}$

Similarly, she discussed Zulu bird knowledge. Her encounter with the first Church of England Bishop of Natal John William Colenso (1814-1883) seemingly influenced her view of the amaZulu. Colenso had helped to translate the Bible into isiZulu. His co-worker, a Zulu philosopher William Ngidi (c. 1830-?), had queried some passages, which had initiated Colenso's biblical criticism. ${ }^{80}$ This as well as his appreciative views on the amaZulu had provoked a scandal in both the Cape Colony and Britain. ${ }^{81}$ Barber's encounter with Colenso confirmed her religious doubts, and she found that they had much in common. He had also had a deep impact on her brother James Henry Bowker, who was sympathetic to the amaZulu and learned much from them about nature. ${ }^{82} \mathrm{He}$ 'very often [found] that there is something behind the scenes in the queer tales which the natives relate regarding animals' ${ }^{83}$ Barber mentions how the amaZulu in Natal described the crested eagle (Spizaetus occipitalis) or bush hawk as a 'Guide Bird', as it guided herders to their missing cattle. ${ }^{84}$ Bowker had written to her about this, which entirely convinced her. She also reports having learned that the adjutant (Leptoptilos crumeniferus) followed sportsmen and indicated their quarry to vultures and jackals. She did not believe this at first, but then argued:

I cannot vouch for the truth of this statement. I have merely given it as it has, upon several occasions, been related to me. There may be something in it. I have seen so many instances of the wonderful sagacity of birds, that at 
all times I hesitate to cast aside as idle gossip any of these strange traditionary tales. The bird may have some ulterior object in feeding the vultures and the jackals, even as the "honey guide" (Cuculus Indicator) has in leading the bee-hunter to the hives of the wild bee. Possibly, like that bird, the adjutant may return to the spot to pick up the fragments that are left behind. ${ }^{85}$

By describing Africans' knowledge of birds as 'traditionary tales', she differentiated between scientific observation that circulated in journals and other scientific publications, and oral tradition. The term suggests that she saw her observations as more rational and thus superior. She was also highly aware and exercised care in making sure that her readers would not criticise her for being too sympathetic with the amaZulu. So Barber quoted Bowker stating that he was not 'a negrophilist', but that he 'dearly love[d] fair play in all [their] dealings, so that in the years to come [they] have no regrets with regard to [their] former proceedings' ${ }^{86}$ This statement summarises Barber's general practice, which was to intermediate between Africans and Europeans, and to appreciate what Africans knew but not see them as equals. Instead, she felt she could adapt the information gained from them to a Western framework, thereby appropriating that data.

Barber and Bowker's practice continued well into the twentieth century, with more or less requirement for justification of racial politics in South Africa depending on the political situation. Like them, the British ornithologist Jack Vincent (1904-1999) during apartheid argued that it was not his 'custom to fraternize with natives', but that his 'native servant "Ali" was 'an absolute "white man," and one of the very best'. ${ }^{87}$ More open to insights by his Zulu informants had been his colleague Austin Roberts (1883-1948), the best-known ornithologist of South Africa, who in 1907 had been perplexed by the relationship between the pin-tailed whydah and the common waxbill's nest. He learned that the amaZulu had a 'saying that young "King-red-beak" is reared out of every "rooibekje's" nest'. Apparently, this solved the problem that had occupied him: 'It is well known how often the superstitions of the observant natives have been found to be based upon fact, and this, I have no doubt, is another instance', ${ }^{88}$ that allowed him to explain the case of parasitism. Some of his colleagues criticised him for relying on 'a negro proverb', 89 but Roberts defended his method and the amaZulu were eventually proved right. Barber, Bowker, Vincent and Roberts all stressed their informants' trustworthiness and their own control over their African associates' routines. ${ }^{90}$ All of them credited their informants' 'soft facts', but the recording of 'hard facts' was exclusively white. ${ }^{91}$ 


\section{TaXidermists and Their Impact on Ornithology}

Far less is known about African taxidermists, and the sources are scarcer, which is why the following section is shorter and more speculative.

Taxidermy originated in Africa. ${ }^{92}$ While Western apothecaries and astrologers had displayed single prepared animals since the Middle Ages, taxidermy was later claimed and is still generally misunderstood to have emerged in Denmark, England, France and Germany in the eighteenth century. Yet as early as 2200 BCE, embalmed animals often accompanied Egyptian mummies, the earliest form of the art. ${ }^{93}$

Since then, animal skins have been preserved for centuries all over the world. By the nineteenth century, there were people everywhere who had mastered the skills of taxidermy. Taxidermy now followed the same principles even though it developed out of independent knowledge and traditions of how to stuff animals. There was no distinct tradition at the Cape.

John Edmonstone, a freed slave from the Demerara region of Guyana, South America, for instance, taught Charles Darwin how to prepare birds in Edinburgh. Edmonstone earned his livelihood stuffing birds which according to Darwin 'he did excellently', and he was a popular taxidermy instructor as he only charged a guinea an hour. Darwin took lessons every day for two months between February and April 1826. Darwin 'often used to sit with him for he was a pleasant and intelligent man'. ${ }^{94}$ This enabled Darwin's work with birds, which became important as his Galápagos finches, which the ornithologist John Gould classified for him as those of a single genus in 1837 , convinced him of his theory of natural selection..$^{95}$ There are no visual sources of African taxidermists in the nineteenth century, and there are no contemporary images of Darwin and John Edmonstone's collaboration, just a watercolour entitled 'In the Workshop of Taxidermist' by the Russian artist Viktor Yevstafiev (1916-1989) from 1948 (Fig. 3.2).

The lighting is interesting and points to a moment of epiphany. Darwin looks charmed, captivated almost to the point of being hypnotised or enamoured, and illuminated just by observing how Edmonstone prepares birds; the watercolour paints this scene as a key moment in Darwin's career.

At the Cape, there were many taxidermists such as Edmonstone who had previously been shown how to prepare birds and then worked for Western explorers and their museum collections in the making. There was 


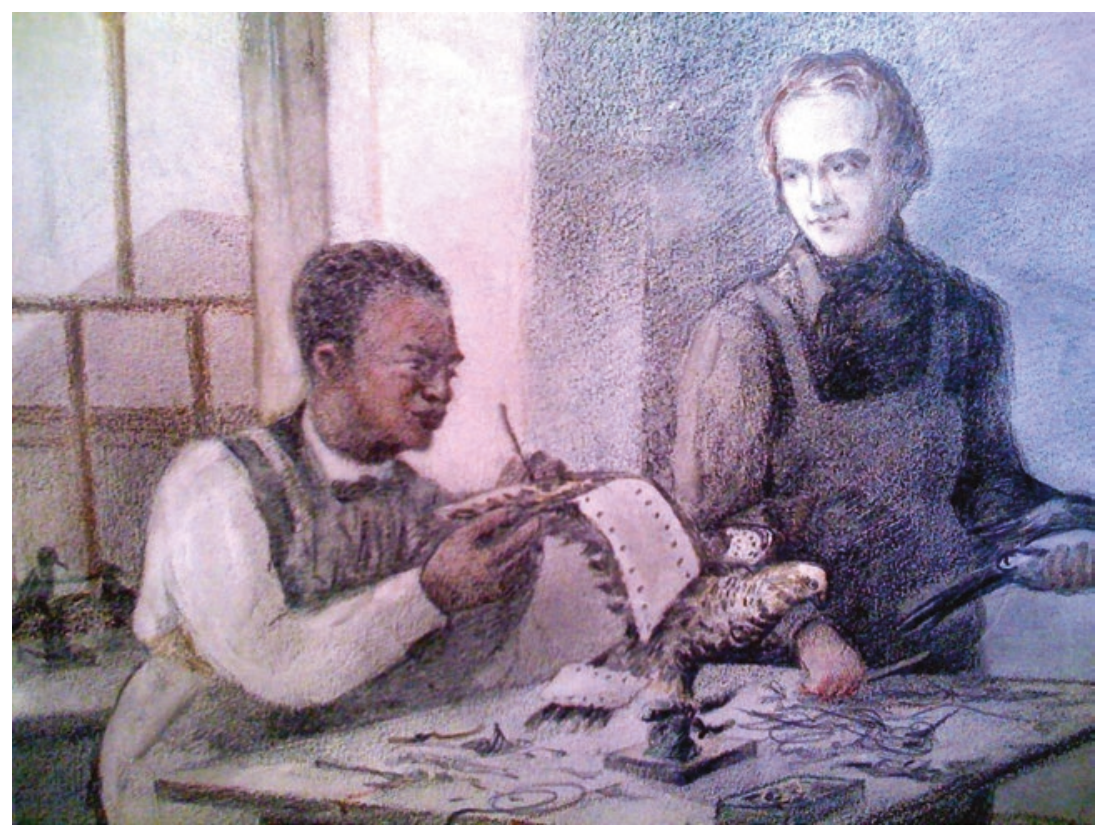

Fig. 3.2 John Edmonstone and Charles Darwin preparing birds. 'In the Workshop of Taxidermist' by Viktor Yevstafiev, 1948. ( State Darwin Museum, Moscow)

no distinct tradition at the Cape, but African taxidermists were important for the development of science and museum archives in the nineteenth century.

Jacobs has shown how European and American ornithologists trained and relied on African taxidermists while doing ornithological research in Southern Africa in the twentieth century. She particularly focuses on the South African museum preparator Saul Sithole (1908-1997). ${ }^{96}$ However, this was by no means a twentieth-century phenomenon. There had been a long tradition of doing so.

The Scottish naturalist Andrew Smith had already acknowledged his batman John Mintern whom he had previously instructed in taxidermy and who stuffed and prepared birds for him. ${ }^{97}$ The birds that Mary Barber donated to the Albany Museum in Grahamstown and the South African Museum in Cape Town had been killed and stuffed by 'the boys'. ${ }^{98}$ These 
'boys' were most likely Xhosa and Mfengu men co-operators. ${ }^{99}$ The Albany Museum taxidermist, a Mr. Adams ${ }^{100}$ who was the local expert, and Edwin Atherstone, the curator of the ornithological collection, may have had a Xhosa and Mfengu team whom they introduced to collecting and preparing the birds. The German missionary Albert Kropf noted that the older Xhosa boys spent a good deal of time catching birds. ${ }^{101}$ They may have sold some of their prey. George Latimer Bates in southeast Cameroon in the twentieth century closely collaborated with 'Bulu boys', whom he described as 'good ornithologists' and included in his community of expertise. While constantly referring to them, he too infantilised these much-respected men with the generic term 'boys' ${ }^{102}$ While Barber also had her relatives to help her collect specimens and a network of colonial scientists with whom she corresponded, as shall be explained in Chap. 4, Bates was on his own and depended much more on his 'Bulu' coworkers, whom he credited accordingly.

While sources on African taxidermists in the nineteenth century are scarce, this does not mean that there were none. On the contrary, little hints in textual sources such as those discussed by Smith and Barber indicate that Western explorers collaborated with African taxidermists. African taxidermists had either previously been trained on how to prepare animal skins or been instructed by their current employers. This enabled labour division and specialisation on expeditions. Settler and European naturalists as well as other African experts could in the meantime focus on other branches of their research. While studies on African informants and collectors have advanced in recent years, ${ }^{103}$ the impact of African taxidermistsparticularly on ornithology—has hardly been explored and deserves much more attention.

In line with the Xhosa saying Intaka yaka ngo-boya bezinye [A bird builds with other birds' feathers], ${ }^{104}$ Barber and her contemporaries depended heavily on African experts. Scientific knowledge of the natural world in South Africa has always been cross-culturally co-produced. Collaboration did not cease in the last third of the nineteenth century. Co-operation was as intense as ever even though Barber did not go into as much detail as Burchell. Barber's descriptions of African experts were influenced more by racist stereotypes, but she depended no less on Africans. An aspect I have emphasised is that European experts did not add African experts' information to 'Western science' without acknowledging the source. They definitely did not suppress their African counterparts and silence their knowledge altogether. Instead, there was a series of 
transformations, and Africans and Europeans were in a relationship of 'parasitic symbiosis', ${ }^{105}$ where Gert and Speelman, for instance, both benefited from their salary, and Speelman had the opportunity to travel to places he had long wanted to visit and bring his wife along. He thus had the possibility to choose this work among other available options and could negotiate conditions. These examples are not representative, and African co-workers joined expeditions on varying terms, but they all had considerable agency and with their wishes and expectations could negotiate parts of their contracts, including what kind of work they would do.

The cases discussed above have also shown that European men and women differently related to their African associates. While men narrowed their dependence on one exceptional African man, their confidant and partner, this narrative was not available for women, who would have appeared sexualised and inappropriately close to a black man and therefore tended to remain vague on who their co-operators were.

Part I has focused on the accumulation of information on plants and animals as well as their acquisition. Part II concentrates on collaboration and competition at the Cape particularly between British and Cape Colonial naturalists on how new classificatory and scientific practices were forged and new theories were developed. In the following chapters, I will demonstrate that the dichotomy between colonies as data-collecting grounds and metropoles as places of theorising does not hold. Both spaces thus need to be analysed within the same framework to make sense of how knowledge was created, circulated and what the political implications were.

\section{Notes}

1. Concept established in (Latour 1987, 225-227), discussed in David Jones, "In Conversation with Bruno Latour: Historiography of Science in Action" (Fall 2005), particularly 1-2. http://ocw.mit.edu/courses/science-technology-and-society/sts-310-history-of-science-fall-2005/ assignments/paper2.pdf, date accessed 27 May 2016.

2. (Jacobs 2016, 95).

3. Unfortunately, I can only paint a rather incomplete picture on who Barber's collaborators were, unlike Jacobs has done on the northern Mozambique-born Jali Makawa (c.1914-1995), the 'number one African collector of the continent' (Jacobs 2016, 163), who features prominently in (Jacobs 2016, 148-179).

4. (Beinart 1998, 780).

5. Quoted in (Beinart 1998, 782). 
6. (Burchell 1824a, 1:166).

7. (Burchell 1824a, 1:167).

8. (Burchell 1824a, 1:168, 354).

9. (Burchell 1824a, 1:183).

10. (Burchell 1824a, 1:245).

11. (Burchell 1824a, 1:260-261).

12. (Burchell 1824a, 1:354).

13. (Burchell 1824b, 2:102).

14. (Burchell 1824b, 2:279).

15. (Burchell 1824b, 2:353, 379).

16. (Burchell 1824b, 2:354).

17. (Burchell 1824b, 2:372).

18. (Burchell 1824a, 1:374, 422-423, 427, 431, 550; 1824b, 2:69, 72, 238, $455)$.

19. (Burchell 1824a, 1:500, 518-519).

20. (Burchell 1824a, 1:519).

21. (Burchell 1824a, 1:283, 501).

22. (Burchell 1824b, 2:491).

23. (Burchell 1824a, 1:500).

24. (Burchell 1824b, 2:27).

25. (Burchell 1824b, 2:72-73).

26. (Burchell 1824b, 2:210).

27. (Burchell 1824b, 2:344).

28. (Burchell 1824b, 2:332).

29. (Craig and Hummel 1994, xxiv-xxv).

30. See for example: (Craig and Hummel 1994, 3, 25, 26, 39, 41, 116, 130).

31. (Craig and Hummel 1994, xxvi; 41-42, 109, 115, 144).

32. See for example: (Craig and Hummel 1994, 41, 47, 49, 90, 96, 'work on the apes all day' does not indicate whether he referred to 'I' or 'we', 48).

33. (Craig and Hummel 1994, 63, 70, 74).

34. (Craig and Hummel 1994, 69, 70).

35. (Craig and Hummel 1994, 69, 72, 86, 98, 99, 140).

36. (Holub 1881, 2:124, 134).

37. (Holub 1881, 2:203).

38. George McCall Theal 1888, 124 quoted in: (de Zwart 2013, 40).

39. For more information see (Bank 1991).

40. (de Zwart 2013, 40).

41. http://www.mises.co.za/2011/12/a-short-history-of-gold-in-thesouth-african-monetary-system/, date accessed 19 September 2016.

42. (Holub 1881, 2:149).

43. (Holub 1881, 2:106-107, 145).

44. Ornithological informant Gert lecturing on the mâ-hem (Holub 1881, 2:147). See (Jacobs 2016, 10). 
45. Not the one seated at the front left, as Jacobs has claimed (Jacobs 2016, $10)$.

46. (Holub 1881, 2:147).

47. Athletic 'Batlapin boys' hunting birds with the kiri. (Holub 1881, 2:opposite 109).

48. (Holub 1881, 2:108). Also see another hunting illustration that shows how he admired the technique: 'A Yochom of the Kalahari chasing a Blessbock', (Holub 1881, 2:259-260).

49. See the stories from the US frontiers, for example, the relationship between the frontiersman Natty Bumppo, Major Duncan Heyward, and the Indians Chingachgook and Uncas in James Fenimore Cooper's historical novel The Last of the Mohicans: A Narrative of 1757 (1826).

50. (Jacobs 2006, 580-581; Jacobs 2016, 121-123).

51. See for example: Old Shatterhand and Winnetoe in German author Karl May's (1842-1912) Winnetou I-III or Winnetou der Rote Gentleman I-III (1893).

52. (Cohen 2011, 20).

53. Perhaps Peter Heinrich Pohlmann in Cape Town. Bertram Egerton Bowker, Reminiscences, HM, SM 57(b), 3.

54. KLAA, Director's Correspondence, Vol. 189, Letter 105, Barber to J. D. Hooker, Highlands, 9 March [1869?].

55. Alan Cohen private archive, London, Nature Tales, no 30, 'The Swallows', copy of manuscript.

56. (Godfrey 1941, 73).

57. (Godfrey 1941, 73).

58. (Burchell 1824a, 1:30).

59. Barber to Mary Layard Bowker, Serial No 044 Grahamstown, 16 January 1886.

60. CL, MS 10560 (c), Vol. 3, 88, italics underlined in original.

61. CL, MS 10560 (c), Vol. 3, 91-92.

62. See for example (Brown 1987); (Cornwell 1996); (Law 2016, "Psychological panics: 'Black Peril' and the regulation of colonial sexualities," 29-30, also see: 34, 163).

63. Saunders reported having local assistants who collected botanical specimens, bulbs and seeds for her, see (Bayer 1979); University of Cape Town, Manuscripts and Archives Department, BC 234, Bolus Papers, C, Botanical Correspondence with Bolus Herbarium, Saunders, Katherine 1885-1890; eleven folios of floral paintings, and copies of correspondence with Kew Gardens, Amazyana Archive, Tongaat; Five folios at the KwaZulu-Natal Museum, Archive and Library, Pietermaritzburg; Alice Pegler apparently primarily collected with her nieces, see Bolus Papers BC 234, C, correspondence P, Pegler, Alice 1894-1914; Arabella Roupell 
did not leave any written account, see (Anonymous 1849); Marianne North mainly relied on Dutch and British settlers who might have sent African employees to collect flowers for North, which is not recorded in North's diary, see for example (North 1894, 2:218, 219, 222, 228, 231, $233,239,242,244,247,248,251,253,257,266)$.

64. My translation of: 'Keine Nacht ruhig geschlafen, bei Tag von schwarzem, zweibeinigem Gesindel geplagt, das sich höher dünkt in ihrem Dummstolze als der Weiße; alles, was die Augen erblicken, bettelnd und wenn nicht gutwillig gegeben, ohne weiteres fassend'. Mauch, Journal No. 4, Sunday, 6 August 1871, quoted in (Schütte 2013, 43).

65. (Schütte 2013, 42-50).

66. Wilson 1936, 10-11 quoted in (Bank and Bank 2013, 75).

67. (Holub 1881, 2:262).

68. (Godfrey 1941). For more on Godfrey see: Cornelius Plug, "Godfrey, Robert", S2A3 Biographical Database of Southern African Science, http://www.s2a3.org.za/bio/Biograph_final.php?serial=1075, last updated 25 December 2014, date accessed 4 September 2016. Experts and archivists confirmed that this was the earliest source on Xhosa knowledge of birds: Prof. Adrian Craig, Dept Zoology \& Entomology, Rhodes University, Grahamstown to T. H., Personal Correspondence, 20 June 2014; Margaret Koopman, Niven Library, DST/NRF Centre of Excellence at the Percy FitzPatrick Institute of African Ornithology (UCT), to T. H., 13 June 2014; Elizabeth de Wet, CL, to Tanja Hammel, 15 September 2014. For a more recent study see (Gijsbertsen 2012).

69. (Layard 1869, 68).

70. (Jacobs 2016, 85).

71. (Jacobs 2016, 4).

72. Indicator Major - White-backed Honey-Guide in: (Richard Bowdler Sharpe 1884, 168-169).

73. Mary E. Barber, "A Plea for Insectivorous Birds: A Paper by Mrs. F. Barber", HM, SM 5501 (46), (Grahamstown: Richards and Slater, 1886), 10.

74. (Barber 1898, 80).

75. (Godfrey 1941, 69-70).

76. (Sparrman 1776). For more on Sparrman see for example (Jacobs 2016, 3, 19); (Beinart 1998, 778, 781).

77. (Theal $1882,29-46)$. Because he left Lovedale in 1877 , it took him until his stay in London in 1882 for its publication (Saunders 1981, 158).

78. (Gijsbertsen 2012, 47-48).

79. (Layard 1867, 105).

80. It started with the publication of The Pentateuch and the Book of Joshua Critically Examined (1862). See for example (Guy 1997). 
81. Barber, Wanderings, Vol. 3, MS 10560 (c), 101.

82. Barber, Wanderings, Vol. 3, MS 10560 (c), 118.

83. Barber, Wanderings, Vol. 3, MS 10560 (c), 116-17, italics mine.

84. Barber, Wanderings, Vol. 3, MS 10560 (c), 116-117.

85. (Barber 1880, 202).

86. Barber, Wanderings, Vol. 3, MS 10560 (c), 137.

87. (Jacobs 2016, 108).

88. Quoted in (Jacobs 2016, 106-107), italics mine.

89. (Jacobs 2016, 107).

90. See (Raffles 2002).

91. (Jacobs 2016, 147).

92. For an interesting study on the relations between taxidermy, collecting and the South African Empire see: (Witz 2015).

93. (Browne 1884, 1-2).

94. C. R. Darwin to S. E. Darwin, Edinburgh, 29 January 1826, Letter 22; (Darwin 1958, 51).

95. (Darwin 1871, 2:37); C. R. Darwin to S. E. Darwin, Edinburgh, 29 January 1826, Letter 22; (Darwin 1958, 51); (Freeman 1978). Most information has been collected in (Desmond and Moore 2010, 18-26); (Voss 2007, 27-94).

96. See (Jacobs 2016, 180-210).

97. (Jacobs 2016, 98).

98. Albany Natural History Society, The Grabam's Town Journal, 22 November 1867; 27 May 1868.

99. Unfortunately, the curators at both institutions were unable to trace an example of a stuffed bird. They were presumably damaged by insects or in the 1941 fire at the Albany Museum and are no longer part of their current collections.

100. He had offered to stuff birds or mammals for the Society and was appointed as the first paid official of the museum in February 1861 at an annual salary of $£ 50$. N. Fowler, A History of the Albany Museum, 1855-1958, HM, Manuscript 1968, [no archival reference number], 23-24.

101. (Kropf 1889, 124), italics mine.

102. (Jacobs 2016, 121). Also see (Latimer Bates 1930).

103. See for example (Witz 2015); (Jacobs 2006; Jacobs 2016).

104. (Soga 1931, 332).

105. (Roque 2010, 18). 


\section{REFERENCES}

Anonymous. 1849. Specimens of the Flora of South Africa: Cape Flowers by a Lady. London: Shakespeare Press of Pall Mall.

Bank, Andrew. 1991. The Decline of Urban Slavery at the Cape, 1806 to 1843, Communications. Vol. 22. Rondebosch: Centre for African Studies, University of Cape Town.

Bank, Andrew, and Leslie Bank. 2013. Inside African Anthropology: Monica Wilson and Her Interpreters. Cambridge: Cambridge University Press.

Barber, M.E. 1880. Locusts and Locust Birds. Transactions of the South African Philosophical Society 1: 193-218.

- 1898. The Erythrina Tree and Other Verses. London: Printed for Private Circulation.

Bayer, Adolph W. 1979. Flower Paintings of Katharine Saunders: Botanical and Biographical Notes and Explanations. Tongaat: Tongaat Group.

Beinart, William. 1998. Men, Science, Travel and Nature in the Eighteenth and Nineteenth-Century Cape. Journal of Southern African Studies 24: 775-799.

Brown, Barbara. 1987. Facing the 'Black Peril': The Politics of Population Control in South Africa. Journal of Southern African Studies 13: 256-273.

Browne, Montagu. 1884. Practical Taxidermy: A Manual of Instruction to the Amateur in Collecting, Preserving, and Setting Up Natural History Specimens of All Kinds .... 2nd ed. London: L. Upcott Gill.

Burchell, William J. 1824a. Travels in the Interior of Southern Africa. Vol. 1. 2 vols. London: Longman, Hurst, Rees, Orme, Brown, and Green. https://doi. org/10.5962/bhl.title.109918.

- 1824b. Travels in the Interior of Southern Africa. Vol. 2. 2 vols. London: Longman, Hurst, Rees, Orme, Brown, and Green. https://doi.org/10.5962/ bhl.title.109918.

Cohen, Alan. 2011. In A Quiet Way: The Life of Mary Elizabeth Barber, South Africa's First Lady Natural Historian 1818-1899. Unpublished Manuscript.

Cornwell, Gareth. 1996. George Webb Hardy's The Black Peril and the Social Meaning of 'Black Peril' in Early Twentieth-Century South Africa. Journal of Southern African Studies 22: 441-453.

Craig, Adrian, and Chris Hummel, eds. 1994. Johan August Wablberg: Travel Journals (and some letters) South Africa and Namibia/Botswana, 1838-1856, Van Riebeeck Society Second Series 23. Cape Town: Van Riebeeck Society.

Darwin, Charles. 1871. The Descent of Man and Selection in Relation to Sex. Vol. 2. 2 vols. New York: D. Appleton and Company.

1958. In The Autobiography of Charles Darwin 1809-1882, with Original Omissions Restored, edited with Appendix and Notes by His Grand-Daughter, ed. Nora Barlow. London: Collins. 
Desmond, Adrian, and James Moore. 2010. Darwin's Sacred Cause: Race, Slavery and the Quest for Human Origins. London: Penguin Books.

Freeman, R.B. 1978. Darwin's Negro Bird-Stuffer. Notes and Records of the Royal Society of London 33: 83-86.

Gijsbertsen, Jaap. 2012. Birds in the AmaXhosa World: An Ethno-ornithological Exploration of the Cultural Significance of Birds, and Its Potential for Conservation in South Africa. Department of Forest and Nature Conservation, Wageningen University.

Godfrey, Robert. 1941. Bird-Lore of the Eastern Cape Province, Bantu Studies, Monograph Series 2. Johannesburg: Witwatersrand University Press.

Guy, Jeff. 1997. Class, Imperialism and Literary Criticism: William Ngidi, John Colenso and Matthew Arnold. Journal of Southern African Studies 23: 219-241.

Holub, Emil. 1881. Seven Years in South Africa, Travels, Researches, and Hunting Adventures, Between the Diamond-Fields and the Zambesi, 1872-79. Vol. 2. London: Sampson Low, Marston, Searle \& Rivington.

Jacobs, Nancy J. 2006. The Intimate Politics of Ornithology in Colonial Africa. Comparative Studies in Society and History 48: 564-603.

- 2016. Birders of Africa: History of a Network. New Haven/London: Yale University Press.

Kropf, Albert. 1889. Das Volk der Xosa-Kaffern im östlichen Südafrika nach seiner Geschichte, Eigenart, Verfassung und Religion. Ein Beitrag zur afrikanischen Völkerkunde. Berlin: Buchhandlung der Berliner evangelischen Missionsgesellschaft.

Latimer Bates, George. 1930. Handbook on the Birds of West Africa. London: John Bale, Sons and Danielsson.

Latour, Bruno. 1987. Science in Action: How to Follow Scientists and Engineers Through Society. Cambridge, MA: Harvard University Press.

Law, Kate. 2016. Gendering the Settler State: White Women, Race, Liberalism and Empire in Rhodesia, 1950-1980. New York/London: Routledge.

Layard, Edgar Leopold. 1867. The Birds of South Africa: A Descriptive Catalogue of all the Known Species Occurring South of the 28th Parallel of South Latitude. Cape Town/London: Juta/Longman, Green \& Co.

. 1869. VI. Further Notes on South-African Ornithology. Ibis 11: 68-79.

North, Marianne. 1894. Recollections of a Happy Life: Being the Autobiography of Marianne North, edited by her sister Mrs. John Addington Symonds, ed. John Addington Symonds. Vol. 3. 3 vols. New York/London: Macmillan.

Raffles, Hugh. 2002. Intimate Knowledge. International Social Science Journal 173: 325-335.

Roque, Ricardo. 2010. Headhunting and Colonialism: Anthropology and the Circulation of Human Skulls in the Portuguese Empire, 1870-1930. New York: Palgrave Macmillan.

Saunders, Christopher. 1981. George McCall Theal and Lovedale. History in Africa 8: 155-164. 
Schütte, Michael. 2013. Die „Entdeckung der Ruinen von Zimbaoe“: Zur Erfindung „weißer Geschichte“ in „Schwarzafrika“ 1871-1872. Magisterarbeit, Göttingen: Seminar für Mittlere und Neuere Geschichte, Philosophische Fakultät, Georg-August-Universität Göttingen.

Sharpe, Richard Bowdler. 1884. The Birds of South Africa, Part VI. London: Bernhard Quarith.

Soga, John Henderson. 1931. The Ama-Xosa: Life and Customs. Alice: Lovedale Press.

Sparrman, Andres. 1776. A Voyage to the Cape of Good Hope, Towards the Antarctic Polar Circle, and Round the World: But Chiefly into the Country of the Hottentots and Caffres, from the Year 1772 to 1776. 2 vols. London: G.G. J. and J. Robinson.

Theal, George McCall. 1882. Kaffir Folk-Lore; or, A Selection from the Traditional Tales Current Among the People Living on the Eastern Border of the Cape Colony. London: W. Swan Sonnenschein.

Voss, Julia. 2007. Darwins Bilder: Ansichten der Evolutionstheorie 1837-1874. Frankfurt a. M: S. Fischer Verlag.

Witz, Leslie. 2015. Hunting for Museums. Journal of Southern African Studies 41: 671-685.

Young, Cheryl Ann. 1994. A Study of the Personal Literature Written in Eastern Cape. MA-thesis, Rhodes University, Grahamstown.

de Zwart, Pim. 2013. Real Wages at the Cape of Good Hope: A Long-Term Perspective 1652-1912. Tijdschrift voor Sociale en Economische Geschiedenis 10: 28-58.

Open Access This chapter is licensed under the terms of the Creative Commons Attribution 4.0 International License (http://creativecommons.org/licenses/ by $/ 4.0 /$ ), which permits use, sharing, adaptation, distribution and reproduction in any medium or format, as long as you give appropriate credit to the original author(s) and the source, provide a link to the Creative Commons licence and indicate if changes were made.

The images or other third party material in this chapter are included in the chapter's Creative Commons licence, unless indicated otherwise in a credit line to the material. If material is not included in the chapter's Creative Commons licence and your intended use is not permitted by statutory regulation or exceeds the permitted use, you will need to obtain permission directly from the copyright holder.

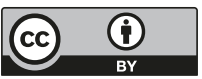

